\title{
Assessing Strategy Relatedness in \\ Highly Diversified Firms
}

\author{
Jeffrey S. Harrison \\ Ernest H. Hall, Jr. \\ Clemson University \\ Clemson, South Carolina \\ Lee G. Caldwell \\ Novell, Inc. \\ Salt Lake City, Utah
}

Since its inception, the field of strategic management has been largely dominated by diversification studies. The primary hypothesis in these studies has been that relatedness among the business units of a corporation should lead to synergy and thus higher performance for the corporation as a whole [39]. Although an enormous amount of research has been generated on the importance of relatedness, or lack thereof, inconsistent and contradictory findings have encouraged controversy. Some studies find that related diversification is associated with higher performance ([3], [32], [39], [42]), while others find the reverse to be true ([14], [29]). In addition, researchers in related fields of study, such as industrial organization in economics, have been unable to establish a consistent relationship between diversification and performance $([2],[15],[25])$, and merger studies on the subject have likewise been inconclusive ([1], [8], [23]).

Even when the importance of the relatedness hypothesis is rejected, dissension exists over which types of relatedness are most relevant, with Biggadike [5], Didrichsen [13], Hopkins [18], Howeil [19], and Rumelt [39] each proposing different typologies of relatedness. This lack of consensus among researchers may have contributed to the contradictions found in research studying the relatedness-performance relationship. Furthermore, the widely-used grouping methodologies found in most diversification studies are unlikely to lead to a consensus since they do not allow for a direct comparison of different types of relatedness.

For example, the categories of Rumelt's [39] typology, which are still widely used in diversification research, were intuitively developed. One of Rumelt's categories is dominant vertical. The dominant vertical category includes firms which are engaged in several different businesses, but which derive greater than $70 \%$ of their revenues from a vertically integrated sequence of processing activities. These vertically integrated firms exhibited low levels of performance in Rumelt's initial study [39]. Does this mean that vertical integration strategies should always be associated with low performance? Not necessarily, since many of the companies in Rumelt's sample may

Journal of Business Strategies, Volume 7, Number 1 (Spring 1990) 
have been using lesser amounts of vertical integration quite successfully in combination with other types of diversification. In summary, the Rumelt methodology is incapable of isolating and assessing the effects of vertical integration on organizational performance when firms are simultaneously engaged in several forms of diversification.

One way of overcoming the methodological problems associated with grouping methodologies is to use continuous measures of relatedness. Continuous measures identify a firm's level or degree of relatedness and eliminate the need for arbitrary decision rules inherent in grouping methodologies. In this study, several continuous measures of relatedness (marketing relatedness, technological relatedness, and vertical integration) are employed in assessing the effects of relatedness on firm profitability, growth, and risk. In addition, the effects of industry structure on the relationship between relatedness and performance are investigated.

\section{The Rationale of Relatedness}

The relatedness concept is built on the idea of "strategic fit." Strategic fit is achieved when businesses are related in some meaningful manner. For example, if businesses complement each other, supplement each other, or use similar resources and skills (marketing, technology, or vertical integration), then the potential for synergy exists ([36], [37]). According to Rumelt, related diversification strategies should outperform unrelated strategies because of the many opportunities for product differentiation, segmentation, development of unique and defensible product-market positions, and shared facilities and marketing channels [39]. Similarities among businesses enable the firm to exploit a particular skill or resource and reap the benefits of a "learning curve" effect [6]. Such inter-business sharing and learning among sister businesses permits the overall firm to become more efficient and thus, more profitable.

Three widely mentioned types of relatedness are vertical integration, technology, and marketing $([5],[13],[18],[19],[39])$. Another frequently mentioned relatedness type, financial, is not explicitly measured in this study. The financial benefits associated with efficient capital allocation and financing are assumed to be available to all of the large highly-diversified firms included in the sample.

\section{Vertical Integration}

Vertical integration provides a firm with the opportunity to expand its business, either forward (into distribution) or backward (into supplies), within the same industry, instead of entering into a new, unfamiliar business. Some of the advantages available to vertically integrated firms include:

1. control of the quality and availability of raw materials or supporting services which are necessary for production;

2 . influence over the manner of presentation of products to end consumers;

3 . enhancement of product quality through greater attention to service;

4. competitive advantages arising from locking out rivals; and 
5. capturing the value added from different stages of production and distribution [16].

Transaction cost theory suggests that vertical integration may also help firms avoid the bargaining costs and opportunistic behavior of suppliers and distributors ([21], [43]).

\section{Technological Relatedness}

Business or products can be classified as being technologically related when they share common skills related to production, operations, machinery, etc. Biggadike [5] classified firms as being technologically related if they developed new ventures using a skill already possessed by the firm. The experience and expertise associated with this skill allows the firm to transfer its learning to a different environment with similar technological processes. The benefits of diversifying on the basis of technological relatedness are evident in the Chrysler/Jeep acquisition.

In addition, economies of scope may arise when equipment used in the production of one product is sufficiently flexible to allow production of other products ([33], [40]). With the increasing sophistication of technology, the ability to manufacture different products using the same equipment offers firms the option of reducing risk by diversifying into technologically familiar areas.

\section{Marketing Relatedness}

Lines of business are marketing related if they benefit from similar marketing skills or marketing channels $([5],[13],[18],[19])$. Whenever products or businesses share the same or similar markets (customers), advertising media, distribution channels, or geographic areas, the potential for marketing synergy exists. Furthermore, marketing researchers argue that the characteristics of goods determine the way they are priced, distributed, and promoted ([7], [11], [30], [34]). Thus, a firm marketing products with similar characteristics should be able to enjoy substantial advertising, distribution, and pricing policy synergies. The RJR/Nabisco acquisition is a good example of the potential for capturing marketing synergies through diversification.

\section{Methods and Hypotheses}

The present study argues that performance differences among highly diversified firms can be explained in part by the degree of relatedness or diversity incorporated along three dimensions: marketing, technology, and vertical integration. Since the intent of this study is to compare and evaluate performance differences among several types of relatedness (as opposed to comparing diversified firms with undiversified firms), only highly-diversified firms are included in the sample.

\section{Sample}

The sample was comprised of 254 highly-diversified firms selected from the 1978 Fortune 500 industrial corporations (all of the firms which met the inclusion criteria). 
The year 1978 was selected for analysis as it is the most recent year for which data used in the vertical integration measure was available. Firms were included in the sample if they were involved in at least six four-digit SIC product groups and two two-digit product groups (similar to Pitts' [35] methodology). The two-digit product group requirements insured that firms were engaged in at least two different technologies. The four-digit product group requirement further insured that firms had some diversity within each technology.

Standard and Poor's Register of Corporations, Directors and Executives [41] was used to identify each firm's four-digit and two-digit SIC codes. Performance data were derived from the Compustat database, annual reports, and Moody's Industrial Manual.

\section{Related Diversification Measures}

Three continuous measures of relatedness were used simultaneously: vertical integration, technological relatedness, and marketing relatedness.

Vertical integration has predominantly been measured using one of three approaches:

1. value added as a percentage of sales (value added);

2. percentage of total product that is part of the vertical chain (vertical ratio); and

3. the Vertical Industry Connection index (VIC).

While value added is easy to calculate, it suffers from two major problems: (1) the ratio is greater for firms involved in extractive processes and (2) factors other than vertical integration (such as profitability) influence the ratio. The vertical ratio used by Rumelt [39] and others is problematic in that it measures horizontal as well as vertical integration. The VIC, while more difficult to calculate, does not suffer from the deficiencies associated with the other measures.

While a detailed mathematical description of the VIC is unfeasible due to space considerations, a brief description is in order. The VIC is derived from the inputoutput matrix of the U.S. economy, which was developed by the Bureau of Economic Analysis, U. S. Department of Commerce. Two industries often serve as input suppliers to each other. The input-output matrix measures these flows from industry to industry. Derived from this matrix, the VIC increases as more of a firm's inputs come from industries in which the firm is involved (backward) or as more of the firm's outputs are used by industries in which the firm is involved (forward). The VIC is a continuous measure having values between 0 (no vertical integration) and 1 (total vertical integration). For more information on the VIC, refer to Maddigan [24].

The technological relatedness measure was a derivative of the number of technologies in which each firm was involved, where a technology was defined by the Bureau of Economic Analysis as containing firms which were involved in some aspect of production for a similar good or service. Technologies were constructed by the Bureau according to similarities with respect to machinery used, type of manufacturing process, operation flow, and type of raw materials used. The Bureau also publishes a 
chart listing each of the four-digit SICs which were contained within each technology. This chart was used to determine the number of technologies in which each firm was involved. The reciprocal of this number was used as the technology measure since it was fund to be a better predictor of firm performance than the raw number of technologies $([20],[22])$. Therefore, a high score on this variable indicated a high degree of technological relatedness (few distinct technologies).

Marketing relatedness was measured along three dimensions: (1) advertising media, (2) distribution methodology, and (3) pricing strategy. Each four-digit SIC product group was classified based on whether the products/services were promoted through television advertising, whether the products/services were distributed directly to end consumers (or were intermediate products), and whether the products/services were priced differently for each customer (custom vs. standard products).

Three marketing variables were created for each firm based on the percentage of firm sales in product groups in each of the three categories. For example, if $30 \%$ of a firm's product groups were distributed directly to the end consumers, it's ratio is .30. Similar ratios were calculated for advertising and pricing. These ratios were then standardized across companies. Returning to the distribution example, this means that high positive values are associated with firms which distribute most of their products to end consumers and high negative values are associated with firms which distribute most of their products to intermediaries in other industries. The potential for synergy exists at both extremes; therefore, the last step in the process is to calculate the absolute values for each of the standardized ratios. This process results in three variables which indicate the potential for high synergy when they are high and low synergy when they are low.

\section{Industry Structure}

The seminal work of Montgomery [31] and other researchers ([4], [9], [10], [31]) demonstrated the importance of industry structure in determining firm performance. The industry structure controls used in this study most closely parallel the work of Montgomery and include variables for concentration, market growth (GROW), industry profitability $(I P R F)$, market share $(M S H R)$, and firm size $(S I Z E)$. Firm specific concentration $(C R 20)$, industry growth, and industry profitability were averaged across all four-digit SIC groups in which the firm participated. Relative market share, or the ratio of a firm's sales to the sales of its largest industry rival, was used as a proxy of market share [17]. Firm size is calculated as a five-year average (19751979) of the reciprocal of the base 10 logarithm of total assets [31].

\section{Performance}

The use of several measures of firm performance assist in overcoming the weakness of using only one measure (vis., adds reliability) and insures this study's comparability with previous research. In accordance with prior research, accounting measures are employed ([10], [31], [39], [40]). 
Profitability, measured as return on assets (ROA) and return on equity (ROE), is averaged over the five years surrounding 1977 (i.e., 1975-1979). An averaging process was employed to reduce the effects of temporary performance variations. Change in sales from 1975 to 1979 is used as a measure of growth. Risk (instability of earnings) is represented by the standard deviation of $\mathrm{ROA}(R R O A)$ and $\mathrm{ROE}(R R O E)$ across the five year time period [4].

\section{Hypotheses and Statistics}

A three-tiered multiple regression analysis was used to isolate the effects of relatedness on performance. First, a series of multiple regressions were run using the five relatedness variables as predictor variables. Multiple regression was used to test the general hypothesis that the nature and extent of related diversification affects firm performance $\left(H_{1}\right)$. Second, the industry variables were introduced and the regressions rerun. Concentration, market share, firm size, market growth, and industry profitability were hypothesized to have positive effects on firm performance $\left(\mathrm{H}_{2}\right)$. Third, a hierarchical regression analysis controlling for industry structure was performed to test the hypothesis that the relatedness variables contributed significantly to the explanation of firm performance even in the presence of industry structure variables $\left(H_{3}\right)$. This three-tiered multiple regression analysis highlighted the importance of industry structure in the strategy/performance relationship.

Table 1

Multiple Regression Equations for the Basic Model

\begin{tabular}{|c|c|c|c|}
\hline \multirow{2}{*}{$\begin{array}{l}\text { Dependent } \\
\text { Variable }\end{array}$} & \multicolumn{3}{|c|}{$\begin{array}{c}\text { Independent Variables } \\
\text { (standard errors in parentheses) }\end{array}$} \\
\hline & $T E C H \quad V I N T$ & $D I S T$ & $P R C E$ \\
\hline \multirow[t]{2}{*}{$R O A$} & $\begin{array}{ll}-.024 & -.007 \\
(.015) & (.009)\end{array}$ & $\begin{array}{ll}.008^{*} & -.002 \\
(.003) & (.003)\end{array}$ & $\begin{array}{l}.003 \\
(.003)\end{array}$ \\
\hline & Int. $=.0639$ & $R^{2}=.0338$ & $p=.1273$ \\
\hline$R O E$ & $\begin{array}{cc}-.103^{* *} & .002 \\
(.029) & (.019) \\
\text { Int. }=.1236\end{array}$ & $\begin{array}{lc}.018^{* *} & .003 \\
(.006) & (.006) \\
R^{2}=.0792\end{array}$ & $\begin{array}{c}.012 \\
(.006) \\
p=.0010\end{array}$ \\
\hline$G S A L$ & $\begin{array}{cc}-.473 & -.037 \\
(.260) & (.168) \\
\text { Int. }=.8031\end{array}$ & 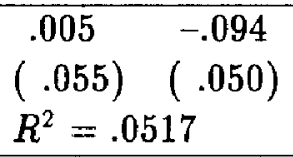 & $\begin{array}{c}-.155^{* *} \\
(.055) \\
p=.0213\end{array}$ \\
\hline RROA & $\begin{array}{lc}.013^{*} & -.002 \\
(.005) & (.004) \\
\text { Int. }=.0142\end{array}$ & $\begin{array}{ll}-.002 & .000 \\
(.001) \quad(.001) \\
R^{2}=.0406\end{array}$ & $\begin{array}{c}-.002 \\
(.001) \\
p=.0662\end{array}$ \\
\hline$R R O E$ & $\begin{array}{cc}.082^{* *} & -.010 \\
(.029) & (.019) \\
\text { Int. }=.0307\end{array}$ & $\begin{array}{lc}-.009 & .000 \\
(.006) & (.006) \\
R^{2}=.0444\end{array}$ & $\begin{array}{c}-.006 \\
(.006) \\
p=.0454\end{array}$ \\
\hline
\end{tabular}




\section{Results}

\section{Basic Model}

The regression equations for the basic model $\left(H_{1}\right)$ are presented in Table 1. The preliminary tests offered some support for the notion that related diversification strategy affects firms performance. Four of the five equations were at least marginally significant $(p<0.10)$. These results suggest that high levels of advertising relatedness $(A D V)$ are associated with high levels of profitability (ROA and $R O E)$. There is also some support for the notion that high technological relatedness $(T E C H)$ is connected with lower profitability (particularly $R O E$ ) and higher risk ( $R R O A$ and $R R O E)$. Also, high pricing relatedness $(P R C E)$ is associated with faster growth $(G S A L)$. As indicated by the regression results, neither vertical integration (VINT) nor distribution relatedness $(D I S T)$ are associated with firm profitability (measured by either $R O A$ or $R O E$ ), growth, nor risk (measured by either $R R O A$ or $R R O E$ ).

\section{Model Adjusted for Industry Structure}

The results of the regression analysis for the complete model $\left(\mathrm{H}_{2}\right)$ are presented in Table 2. All of the equations increased in explanatory power. The results of the complete model parallel the results of the basic model, with the exception of the pricing relatedness variable $(P R C E)$, which is no longer significant. Only one of the coefficients changed sign ( $V I N T$ as an independent variable in the $R O A$ model specification). Importantly, this variable was not significant in either the basic nor the complete model specification.

As hypothesized, industry structure influences firm performance, with industry profitability exhibiting a strong positive relationship with profitability and growth and a strong negative relationship with risk. The other industry structure variables were not significantly associated with profitability, growth, nor risk. Overall, industry profitability was the most important variable in determining firm profitability, growth, and risk.

The results of the hierarchical regression analysis $\left(H_{3}\right)$ are presented in Table 3. The results suggest that industry structure should be included in models investigating the relationship between relatedness and performance, since relatedness contributed significantly to explanatory power after the inclusion of the structure variables in only one case $(R O E)$. However, the findings do not necessarily reduce the importance of the relatedness variables in understanding diversification since firms within an industry often possesses similar corporate strategies [40]. Therefore, relatedness is likely to be significantly correlated with industry profitability, which reduces the influence of the relatedness variables when industry profitability in included in the model. These relationships were found to hold true in the present study. For example, industry return on equity was significantly correlated with vertical integration $(p<$ $0.05)$, technological relatedness $(p<0.01)$, and distribution relatedness $(p<0.01)$. 
Table 2

Multiple Regression Equations ${ }^{a}$ for the Complete Model

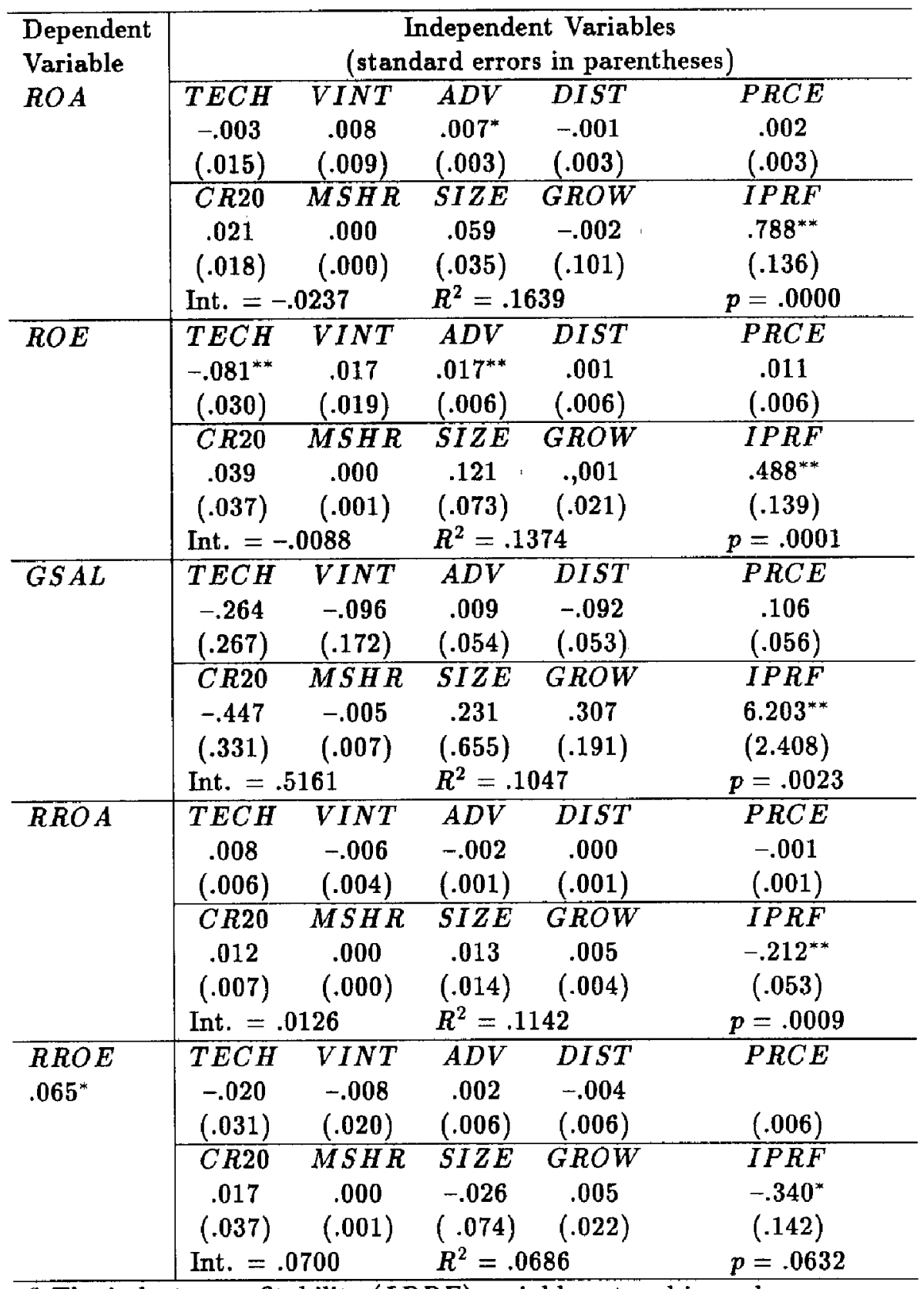

${ }^{a}$ The industry profitability (IPRF) variable entered in each equation corresponding with the dependent variable used. For example, in the $R O A$ equation, average industry $R O A$ was used.

${ }^{*} p<.05$

${ }^{* *} p<.10$ 
Table 3

Tests of Significance of Relatedness Variables After Controlling for Industry Structure

\begin{tabular}{|c|c|c|c|c|c|}
\hline \multirow[b]{3}{*}{ Equation } & \multicolumn{2}{|c|}{ Explanatory Power $\left(R^{2}\right)$} & \multirow{2}{*}{\multicolumn{2}{|c|}{$\begin{array}{l}\text { Significance Test for } \\
\text { Relatedness Variables }\end{array}$}} & \multirow{3}{*}{$\begin{array}{c}\text { Basic } \\
\text { Model } \\
\text { Prob }(F)\end{array}$} \\
\hline & Complete & Structure & & & \\
\hline & Model & Model & $F$ ratio $^{a}$ & $\operatorname{Prob}(F)$ & \\
\hline$R O A$ & 1639 & .1424 & 1.2497 & 2866 & .1273 \\
\hline$R O E$ & 1374 & 0776 & 3.3692 & .0058 & 0010 \\
\hline$G S A L$ & 1047 & .0801 & 1.3354 & 2499 & .0213 \\
\hline$R R O A$ & 1142 & .0878 & 1.4485 & 2076 & .0662 \\
\hline$R R O E$ & 0686 & 0347 & 1.7689 & 1199 & 0545 \\
\hline
\end{tabular}

\section{Discussion and Conclusions}

This study investigated several types of relatedness and their effects on profitability, growth, and risk. The results suggest several conclusions. First, firms with high advertising relatedness had higher profitability without incurring higher risk. That is, firms which had diversified into product groups that were advertised through similar channels may have been better able to fully exploit synergy than firms that extended their product groups across advertising media. Since products that are advertised on television are largely consumer products, these results may be generalizable to traditional consumer vs. industrial product classifications. However, further research is needed for clarification of this issue.

The second important finding of this research is that high technological relatedness appears to be associated with low profitability and high risk. Remember, high technological relatedness implies that a firm is involved in only a few technologies. Therefore, firms which extended their resources into many technologies enjoyed both higher return on equity and reduced risk. This is precisely what financial economists have been saying for years and is consistent with both portfolio theory and transaction cost economics [43].

Consistent with Montgomery's [31] earlier work, the introduction of industry structure variables has significant impact on the relationship between diversity and performance. For example, the pricing relatedness variable lost its significance as a predictor of sales growth in the presence of the structure variables and the group of relatedness variables no longer contributed significantly to an understanding of firm risk. However, the other relationships among relatedness, profitability, and risk remained constant.

Some findings of this research are particularly interesting in light of past research. Several studies ([27], [28], [38]) have discovered a positive relationship between diversity and performance. This study demonstrates that one form of relatedness 
(technological) is associated with lower return on equity, while another (advertising) was associated with higher returns on both equity and assets. McDougall and Round [28] found that diversified firms had less accounting-determined risk, whereas Bettis [3] found that increasing diversity did not lead to a reduction of risk. In this study, technological relatedness (taken as the opposite of diversity) was associated with higher risk, consistent with McDougall and Round. These initial findings suggest that the use of continuous measures of diversity may assist researchers in explaining the contradictions which currently exist in the diversification literature.

In conclusion, this study accomplished three major purposes. First, it demonstrated the practicality of a new methodology for examining diversification strategy. Second, it provided some evidence concerning which types of related diversification influences the performance of a firm. Third, it confirmed the necessity of controlling for industry structure (especially industry proftability) when investigating the relationships between diversification and performance.

\section{Practical Applications}

This study provides evidence which may be helpful to executives making diversification decisions. One commonly stated reason for diversifying is to reduce variability in returns (risk). The present study demonstrates that expanding into multiple technologies can reduce this type of risk and also increase returns. on the other hand, evidence is provided suggesting that it is more profitable to specialize in products which are advertised using similar marketing channels (marketing related). Further, while industry structure affects firm performance in this study, it does not alter these basic relationships. Finally, this resench reinforces the findings of Rumelt and others that vertical integration may not be a profitable strategy.

\section{References}

1. Ansoff, H. I., R. G. Brandenburg, R. E. Portner, and R. Radosevich. Acquisition Behavior of U. S. Manufacturing Firms, 1946-196\%. Nashville, TN: Vanderbilt University Press (1971).

2. Arnould, R. J. "Conglomerate Growth and Public Policy." In Economics of Conglomerate Growth, Corvallis, OR: Oregon State University Department of Agricultural Economics (1969), pp. 72-80.

3. Bettis, R. A. "Performance Differences in Related and Unrelated Diversified Firms," Strategic Management Journal, Vol. 2 (1981), pp. 379-93.

4. Bettis, R. A. and W. K. Hall. "Diversification Strategy, Accounting Determined Risk, and Accounting Determined Return," Academy of Management Journal, Vol. 25 (1982), pp. 254-64.

5. Biggadike, E. R. Corporate Diversification: Entry, Strategy, and Performance. Cambridge, MA; Harvard University Press (1979). 
6. Boston Consulting Group. Perspectives on Experience. Boston, MA: Boston Consulting Group (1968).

7. Bucklin, L. P. "Retail Strategy and the Classification of Consumer Goods," Journal of Marketing, Vol. 27, No. 1 (1963), pp. 50-55.

8. Burgman, R. J. A Strategic Explanation of Corporate Acquisition Success, doctoral dissertation, Purdue University (1983).

9. Chang, Y. and H. Thomas. "The Impact of Diversification Strategy on RiskReturn Performance," Strategic Management Journal, Vol. 10, No. 3 (1989), pp. 271-84.

10. Christensen, H. K. and C. A. Montgomery. "Corporate Economic Performance: Diversification Strategy vs. Market Structure," Strategic Management Journal, Vol. 2 (1981), pp. 327-43.

11. Copeland, M. T. "The Relationship of Consumers' Buying Habits to Marketing Methods," Harvard Business Review, Vol. 1 (1923), pp. 282-89.

12. DeNoble, A. F. "An Analysis of the Association Between an Acquiring Firm's Corporate and Business Level Strategies and Its Resulting Postmerger Managerial Decisions," paper presented at the annual meetings of the Academy of Management, Boston, MA (1984).

13. Didrichsen, J. "The Development of Diversified and Conglomerate Firms in the United States, 1920-1970," Business History Review, Vol. 46 (1972), pp. 202-19.

14. Dolan, M. J. "The Case for the New Conglomerate," working paper, Booz, Allen and Hamilton, New York, NY (1985).

15. Gort, M. Diversification and Integration in American Industry. Princeton, NJ: Princeton University Press (1962).

16. Harrigan, K. R. "Vertical Controls and Corporate Strategy," paper presented at the annual meetings of the Academy of Management, Boston, MA (1984).

17. Hedley, B. "Strategy and the Business Portfolio," Long-Range Planning, Vol. 10, No. 1 (1977), pp. 9-15.

18. Hopkins, H. D. "Acquisition Strategy and Market Structure," Proceedings of the 44th Annual Meeting of the Academy of Management (1984), pp. 17-21.

19. Howell, R. "Plan to Integrate your Acquisitions," Harvard Business Review, Vol. 48, No. 6 (1970), pp. 66-76.

20. Johnston, J. Econometric Methods, second edition. New York, NY: McGraw-Hill (1972). 
21. Klein, B., R. G. Crawford, and A. A. Alchian. "Vertical Integration, Appropriate Rents, and the Competitive Contracting Process," Journal of Law and Economics, Vol. 21 (1978), pp. 297-326.

22. Kleinbaum, D. G. and L. L. Kupper. Applied Regression Analysis and Other Multivariate Methods. Belmont, CA: Wadsworth Publishing Company (1978).

23. Kusewitt, J. B., Jr. "An Exploratory Study of Strategic Acquisition Factors Relating to Performance," Strategic Management Journal, Vol. 6 (1985), pp. 15169.

24. Maddigan, R. J. "The Measurement of Vertical Integration," Review of Economics and Statistics, Vol. 63 (1981), pp. 328-35.

25. Markham, J. W. Conglomerate Enterprise and Economic Performance. Cambridge, MA: Harvard University Press (1973).

26. Markowitz, H. Portfolio Selection - Efficient Diversification of Investments. New Haven, CT: Yale University Press (1959).

27. Martin, S. "Market, Firm, and Economic Performance," The Monograph Series in Finance and Economics, Vol. 1 (1983), pp. 1-72.

28. McDougall, F. M. and D. K. Round. "A Comparison of Diversifying and Nondiversifying Australian Industrial Firms," Academy of Management Journal, Vol. 27 (1984), pp. 384-98.

29. Michel, A. and I. Shaked. "Does Business Diversification Affect Performance?" Financial Management, Vol. 13, No. 4 (1984), pp. 18-25.

30. Miracle, G. E. "Product Characteristics and Marketing Strategy" Journal of Marketing, Vol. 29 (1965), pp. 18-24.

31. Montgomery, C. A. Diversification, Market Structure, and Firm Performance: An Extension of Rumelt's Model, doctoral dissertation, Purdue University (1979).

32. Palepu, K. "Diversification Strategy, Profit Performance, and the Entropy Measure," Strategic Management Journal, Vol. 6 (1981), pp. 239-55.

33. Panzar, J. C. and R. D. Willig. "Economies of Scope," American Economic Review, Vol. 71 (1981), pp. 268-72.

34. Peter, J. P., J. H. Donnelly, Jr., and L. X. Tarpey. A Preface to Marketing Management, revised edition. Plano, TX: Business Publications, Inc. (1982).

35. Pitts, R. A. "Strategies and Structures for Diversification," Academy of Management Journal, Vol. 20 (1977), pp. 197-208.

36. Porter, M. E. Competitive Strategy. New York, NY: Free Press (1985). 
37. Reed, S. F. "Corporate Growth by Strategic Planning. Part II: Developing a Plan," Mergers and Acquisitions, Vol. 12, No. 3 (1977), pp. 4-27.

38. Rhoades, S. A. "The Effect of Diversification on Industry Profit Performance in 241 Manufacturing Industries: 1963," Review of Economics and Statistics, Vol. 55 (1973), pp. 146-55.

39. Rumelt, R. P. Strategy, Structure, and Economic Performance. Cambridge, MA: Harvard University Press (1974).

40. Rumelt, R. P. "Diversification Strategy and Profitability," Strategic Management Journal, Vol. 3 (1982), pp. 359-69.

41. Standard and Poor's Corporation. Standard and Poor's Register of Corporations, Directors, and Executives 1979, Vols. 1-3. New York, NY: Standard and Poor's (1979).

42. Varadarajan, P. and V. Ramanujam. "Diversification and Performance: A Reexamination Using a New Two-Dimensional Conceptualization of Diversity in Firms," Academy of Management Journal, Vol. 30 (1987), pp. 380-97.

43. Williamson, O. E. "Assessing the Modern Corporation: Transaction Cost Considerations." In J. F. Weston (ed.), Large Corporations in a Changing Society, New York, NY: New York University Press (1975).

44. Wrigley, L. Divisional Autonomy and Diversification, doctoral dissertation, Harvard Business School (1970). 